\title{
Electrochemical detection of the toxic dinoflagellate Alexandrium ostenfeldii with a DNA-biosensor
}

\author{
Katja Metfies ${ }^{\mathrm{a}, *}$, Susanne Huljic ${ }^{\mathrm{a}}$, Martin Lange ${ }^{\mathrm{b}}$, Linda K. Medlin ${ }^{\mathrm{a}}$ \\ ${ }^{a}$ Alfred Wegener Institute for Polar and Marine Research, Am Handelshafen 12, 27570 Bremerhaven, Germany \\ b Staatliche Lehr und Forschungsanstalt für Landwirtschaft, Weinbau und Gartenbau, Breitenweg 71, 67435 Neustadt and der Weinstrasse, Germany
}

Received 16 December 2003; received in revised form 19 May 2004; accepted 20 May 2004

Available online 7 July 2004

\begin{abstract}
The steady rise of observations of harmful or toxic algal blooms throughout the world in the past decades constitute a menace for coastal ecosystems and human interests. As a consequence, a number of programs have been launched to monitor the occurrence of harmful and toxic algae. However, the identification is currently done by microscopic examination, which requires a broad taxonomic knowledge, expensive equipment and is very time consuming. In order to facilitate the identification of toxic algae, an inexpensive and easy-to-handle DNA-biosensor has been adapted for the electrochemical detection of the toxic dinoflagellate Alexandrium ostenfeldii. The detection of the toxic algae is based on a sandwich hybridisation, which is carried out on a disposable sensor chip. A set of two probes for the species-specific identification of A. ostenfeldii was developed. The specificity of the probes could be shown in dot-blot hybridisations and with the DNA-biosensor. The sensitivity of the DNA-biosensor was optimised with respect to hybridisation temperature and NaCl-concentration and a significant increase of the sensitivity of the DNA-biosensor could be obtained by a fragmentation of the rRNA prior to the hybridisation and by adding a helper oligonucleotide, which binds in close proximity to the probes to the hybridisation.
\end{abstract}

(C) 2004 Elsevier B.V. All rights reserved.

Keywords: DNA-biosensor; Toxic algae; Alexandrium ostenfeldii; Sandwich hybridisation; Helper oligonucleotide; Disposable sensor chip

\section{Introduction}

The safety and quality of the world's coastal areas is an important issue because they harbour complex ecosystems and represent an important economic source with regards to tourism, fishery and aquaculture. However, blooms of microalgae that are potentially harmful with respect to the ecosystem, public health or economic aspects frequently affect coastal areas. Harmful algae can be classified into three groups. The first group is not toxic, nevertheless, it has the potential to harm the environment by forming dense blooms that can cause an oxygen-depletion that results in indiscriminate kills of fish and other organisms. Toxic algae are assigned to a second group of harmful algae that threaten the environment by the production of very potent toxins, which can cause both animal and human poisoning.

\footnotetext{
* Corresponding author. Tel.: +49 47148311655; fax: +4947148311425 .

E-mail address: kmetfies@awi-bremerhaven.de (K. Metfies).
}

The third group of harmful algae comprises those microalgae that either harm fish mechanically or by the production of haemolytic substances (Hallegraeff, 1993). There are about 300 species known to have the potential to form algal blooms and approximately 85 of theses species are potential toxin producers (Sournia et al., 1991; IOC, 2002). The majority of the known toxic algae species belongs to three divisions: Cyanophyta, Dinophyta and Haptophyta (Fogg, 2002). However, the division Dinophyta contains the largest number of harmful algal species (Taylor, 1985). Among the Dinoflagellates there are about 20 species known to produce potent toxins, for example, saxitoxins that cause the life threatening syndrome paralytic shellfish poisoning (PSP). PSP is caused by the consumption of contaminated shellfish (Hallegraeff, 1993). The dinoflagellate Alexandrium ostenfeldii produces PSP-toxins (Hansen et al., 1992) and other toxins. Recently, new toxins, including the spirolides, produced by the marine dinoflagellate A. ostenfeldii have been isolated. Mammalian toxicity of spirolides was confirmed by mouse bioassays. Spirolides proved to be highly toxic in intraperitoneal injec- 
tions of lipophilic, contaminated shellfish extracts in mice, including neurological symptoms, followed by rapid death (Cembella, 1998; Cembella et al., 2000; Hu et al., 2001). The dinoflagellate A. ostenfeldii is cosmopolitan, it has been observed in the waters of Greenland (Hansen-Ostenfeld, 1913), Norway (Balech and Tangen, 1985), Spain (Fraga and Sanchez, 1985), Denmark (Moestrup and Hansen, 1988), Russia (Konovalova, 1991), Egypt (Balech, 1995), Canada (Cembella et al., 1999) and New Zealand (McKenzie et al., 1996).

In the light of the threats by the toxic algae that occur at the coastlines all over the world (Hallegraeff, 1995) numerous monitoring programs have been launched that observe the phytoplankton composition on a regular basis. This is done not only to initiate testing of toxin in shellfish, but also to serve as an early warning system for fish-farms to avoid economic damage caused by the bloom of a toxic algae that has the potential to kill the caged fish. With regard to this the European Union requires that the member states monitor the water at their coastlines for toxin-producing plankton and toxins in mussels (Directive 91/492d/EC and Commision Decision 2002/225/EC). Monitoring is very labour intensive and costly. It requires the analysis of large numbers of samples. Currently, the identification of phytoplankton cells is done by taxonomy, which is based on a broad expertise of specially trained staff, expensive equipment like electron microscopes and is very time consuming. Therefore, a more rapid, secure and inexpensive method would be welcome by all monitoring programs. In this respect the application of DNA-biosensors could serve the needs of monitoring programs. DNA-biosensors are known from various areas of interest that take advantage of the hybridisation principle e.g., in the face of the mailings of letters containing Bacillus anthracis in fall of 2001 a biosensor for the specific identification of the bacterium was developed (Hartley and Baeumner, 2003). The identification of organisms with a DNA-biosensor is based on specific probes that target DNA-sequences that are only present in the organism of interest. In the past decade, numerous probes have been developed for the identification of phytoplankton and toxic algae, respectively (Scholin and Anderson, 1998; Simon et al., 2000). Here, we present the adaptation of a DNA-biosensor for the electrochemical detection of the toxic dinoflagellate A. ostenfeldii with molecular probes. The technical background of the device was presented in detail previously to the public in the German patent application DE 10032042 A1 (Elektrochemischer Einwegbiosensor für die quantitative Bestimmung von Analytkonzentrationen in Flüssigkeiten). The system is based on two major parts. The first part is a disposable sensor chip and a handheld device for the measurement of the electrochemical signal. The disposable sensor chip consisting of a carrier material harbours a working electrode, on which the detection reaction takes place, a reference electrode and an auxiliary electrode. The working electrode has a diameter of $1 \mathrm{~mm}$ and consists of a carbon paste. A biotinylated probe is immobilised in the reaction

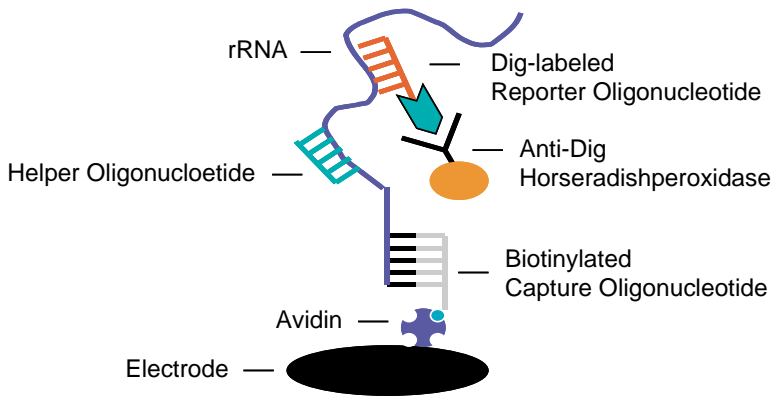

Fig. 1. Principle of the electrochemical detection of nucleic acids by a sandwich hybridisation.

layer of the working electrode via avidin. The nucleic acids are detected on the sensor chip via a sandwich-hybridisation (Zammatteo et al., 1995; Rautio et al., 2003). The underlying principle of this method is that one target specific probe, here called capture probe, is immobilised on the surface of the working electrode. If a target nucleic acid is bound to the immobilised probe on the working electrode, the detection of the nucleic acid takes place via a hybridisation to a second target specific probe, which is coupled to digoxygenin that is recognized by a digoxigenin specific antibody. The antibody in turn is coupled to horseradish-peroxidase that catalyses the reduction of hydrogen peroxide (substrate of the horseradish-peroxidase) to water. The reduced peroxidase is regenerated by $p$-aminodiphenylamin (ADPA), that functions as a mediator. The oxidised mediator gets reduced at the working electrode with a potential of $-150 \mathrm{mV}$ (versus $\mathrm{Ag} / \mathrm{AgCl}$ ) (Fig. 1). In this set up it is only possible to measure an electrochemical signal, if the target nucleic acid as the link between the two probes is present in the system.

\section{Material and methods}

\subsection{Algal strains}

The specificity of the probes targeting the 18S rRNA of $A$. ostenfeldii was tested with the following strains: $A$. ostenfeldii K0287 and K0324 (Scandinavian Culture Centre for Algae and Protozoa, University of Copenhagen), A. ostenfeldii BAH ME 136 (Biologische Anstalt Helgoland, Germany), Alexandrium minutum AL3T (Gulf of Trieste, Italy, A. Beran), Alexandrium lusitanicum BAH ME91 (Biologische Anstalt Helgoland, Germany), Alexandrium pseudogonyaulax AP2T (Gulf of Trieste, Italy, A. Beran), Alexandrium andersonii 012b, Alexandrium taylori AY2T (Lagoon of Marano, Italy, A. Beran), Alexandrium affine CCMP112 (Provasoli-Guillard National Centre for Culture of Marine Phytoplankton, USA), Alexandrium tamarense BAH ME182 (Biologische Anstalt Helgoland, Germany), Alexandrium catanella BAH ME217 (Biologische Anstalt Helgoland, Germany), A. tamarense 31/4 (Cork Habor, Ireland, W. Higman), A. tamarense SZN01 (Gulf of Naples, 16/06/99), Gymnodinium varians CCMP421 
(Provasoli-Guillard National Centre for Culture of Marine Phytoplankton, USA) and Pyramimonas parkae CCMP724 (Provasoli-Guillard National Centre for Culture of Marine Phytoplankton, USA).

\subsection{Culture conditions}

All algal strains were cultured under sterile conditions in seawater-based K-medium (Keller et al., 1987). The cultivation temperature was $15^{\circ} \mathrm{C}$ and the cultures were exposed to a photon irradiance rate of $150 \mu \mathrm{E}-200 \mu \mathrm{E}$ provided by white lamps at a light:dark cycle of 14:10 h.

\subsection{Isolation of nucleic acids}

Total RNA was isolated from algal cultures with the RNeasy Plant Mini Kit (Qiagen, Germany). Genomic DNA was extracted from pure cultures with the DNeasy Plant Mini Kit (Qiagen, Germany).

\subsection{Dot-blot assay}

Prior to the dot-blot analysis, the 18S-DNA of the target organisms was amplified by PCR using the primer $1 \mathrm{~F}$ and 1528R (Medlin et al., 1988). The PCR-fragments were purified with the Qiaquick PCR-Purification Kit (Qiagen, Germany). The dot-blot assay was done according to previous publications (Lange and Medlin, 2002). In this assay, the hybridisation was carried out for at least $12 \mathrm{~h}$ with a probe concentration of $1 \mathrm{pmol} / \mathrm{ml}$ at a hybridisation temperature of $56{ }^{\circ} \mathrm{C}$.

\subsection{Immobilisation of the probes on the sensor chip}

Subsequent to an equilibration with Buffer $1(50 \mathrm{mM}$ $\mathrm{NaHCO}_{3}, \mathrm{pH}$ 9.6), the working electrode was incubated with NeutrAvidin [0.5 mg/ml] (Pierce Biotechnology, USA) for at least $4.5 \mathrm{~h}$ at $4{ }^{\circ} \mathrm{C}$. Excessive NeutrAvidin was removed from the working electrode by washing the sensor with PBS (BupH phosphate saline pack, Pierce Biotechnology, USA). In the following the working electrode was blocked with $3 \%$ [w/v] casein in PBS for $1 \mathrm{~h}$ and washed afterwards in PBS. Prior to the immobilisation the probe was dissolved at a concentration of $10 \mu \mathrm{M}$ in Buffer $2(0.3 \mathrm{M} \mathrm{NaCl} / 0.1 \mathrm{M}$ Tris, $\mathrm{pH}$ 7.6). The electrode was incubated for $30 \mathrm{~min}$ with the probe at room temperature to immobilise the probe on the electrode. To avoid evaporation, all incubations have been carried out in a wet chamber. Excessive probe was removed by washing the sensor with hybridisation buffer $(75 \mathrm{mM}$ $\mathrm{NaCl} / 20 \mathrm{mM}$ Tris, $\mathrm{pH}$ 8.0/0.04\% SDS).

\subsection{RNA-fragmentation}

The fragmentation was carried out in fragmentation buffer (40 mM Tris, $\mathrm{pH} 8.0 / 100 \mathrm{mM}$ KOAc/30 mM MgOAc) at $94^{\circ} \mathrm{C}$.

\subsection{Hybridisation}

Here, we describe a preliminary protocol that was used prior to the adaptations that are presented in this publication. In the following we refer to it as "standard protocol". The hybridisation mix contained $1 \times$ Hybridisation buffer $(75 \mathrm{mM}$ $\mathrm{NaCl} / 20 \mathrm{mM}$ Tris, $\mathrm{pH}$ 8.0/0.04\% SDS), $0.25 \mu \mathrm{g} / \mu \mathrm{l}$ herring sperm DNA, $0.1 \mathrm{pmol} / \mu \mathrm{l}$ dig-labeled probe and rRNA at different concentrations. To denature the target nucleic acid, the hybridisation mix was incubated for $4 \mathrm{~min}$ at $94{ }^{\circ} \mathrm{C}$ prior to the application onto the working electrode. The hybridisation was carried out with $2 \mu$ l of the hybridisation mix for $30 \mathrm{~min}$ at $46^{\circ} \mathrm{C}$. To avoid evaporation the hybridisation was carried out in a water-saturated wet chamber. Subsequent to the hybridisation the sensor chips were washed with Buffer $3\left(50 \mathrm{mM} \mathrm{NaH}_{2} \mathrm{PO}_{4} \times \mathrm{H}_{2} \mathrm{O}, \mathrm{pH} 7.6 / 100 \mathrm{mM}\right.$ $\mathrm{NaCl})$.

\subsection{Detection}

The initial step of the detection reaction was an incubation of $30 \mathrm{~min}$ of the sensor chip with horseradish-peroxidase, which was coupled to an antibody that recognised Digoxigenin (Anti-Dig POD). The sensor chip was incubated with $1.5 \mu \mathrm{l}$ of the horseradish-peroxidase solution $(7.5 \mathrm{U} / \mathrm{ml}$ in PBS, $\mathrm{pH} 7.6 / 0.1 \%$ BSA [w/v]/0.05\% Tween $20[\mathrm{v} / \mathrm{v}])$. Prior to the detection, excessive enzyme was removed by washing the sensor chips with Buffer 3. Subsequent to the washing step the sensor chip was connected to the potentiostat and $20 \mu \mathrm{l}$ of the substrate solution (4-aminophenylamine hydrochloride [44 $\mu \mathrm{g} / \mathrm{ml}] / 0.44 \%$ ethanol [v/v]/0.048\% $\quad \mathrm{H}_{2} \mathrm{O}_{2} \quad[\mathrm{v} / \mathrm{v}] / 50 \mathrm{mM} \quad \mathrm{NaH}_{2} \mathrm{PO}_{4} \quad \times$ $\mathrm{H}_{2} \mathrm{O} / 100 \mathrm{mM} \mathrm{NaCl}$ ) was applied to the working electrode. The electrochemical signal of the detection reaction was measured directly after the application of the substrate solution for $10 \mathrm{~s}$ at a potential of $-150 \mathrm{mV}$ (versus $\mathrm{Ag} / \mathrm{AgCl})$.

\section{Results}

\subsection{Probe design}

For the sandwich-hybridisation two probes that specifically bind to the $18 \mathrm{~S}$-rRNA of $A$. ostenfeldii (Table 1) have been designed using the ARB software package (Ludwig et al., 2004). The probes have at least two mismatches against all non-target organisms listed in the ARB database. The overall specificity of the probes was tested by doing a BLAST search (Altschul et al., 1990) against all public available sequences. To avoid possible effects of degradation of the target nucleic acid the chosen probes were located in close proximity to each other. The distance between the binding sites of the probe set that we present here for A. ostenfeldii was $50 \mathrm{bp}$. 
Table 1

Sequences of the A. ostenfeldii specific probes and the helper oligo $\mathrm{H} 3$

\begin{tabular}{llc}
\hline Probe & Probe sequence & Position in $18 \mathrm{~S}$ rRNA \\
\hline AOST1 & CAA CCC TTC CCA ATA GTC AGG T & 180 \\
AOST2 & GAA TCA CCA AGG TTC CAA GCA G & \\
H3 & GCA TAT GAC TAC TGG CAG GAT C & 232 \\
\hline
\end{tabular}

\subsection{Specificity of the probes}

The specificity of the probes was tested separately for each probe in a dot-blot-assay. The probes were tested against PCR-fragments of the 18S-DNA of those species that had the lowest number of mismatches and that were the nearest neighbour in a phylogenetic tree (John et al., 2003). Additionally the probes were tested against more distantly related species of the genus Alexandrium, G. varians and P. parkae. The dot blot assay exhibited that both of the probes for $A$. ostenfeldii are highly specific. It was possible to observe a hybridisation signal for all tested A. ostenfeldii strains, whereas no hybridisation signal could be observed for any of the non-target organisms (Fig. 2).
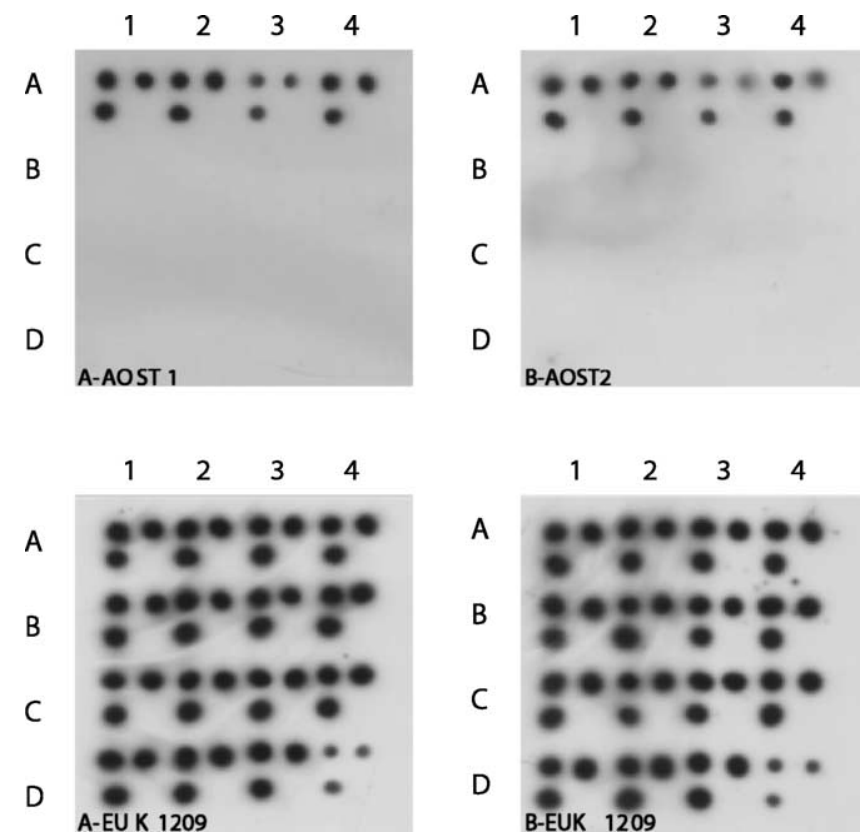

Fig. 2. Dot-blot hybridization. Two filters (A, B) were used for hybrisation. A-AOST1: hybridisation of filter A with AOST1. B-AOST2: hybridisation of filter B with AOST2. A-EUK1209/B-EUK1209: control hybridisation of both filters to the eukaryotic probe Euk1209 (Lim et al., 1993) to ensure equal loading of the target DNA. All filters were spotted with the following pattern: A1: A. ostenfeldii K0287, A2: A. ostenfeldii K0324, A3: A. ostenfeldii BAH ME 136, A4: A. ostenfeldii AOSH1, B1: A. minutum AL3T, B2: A. lusitanicum BAH ME 91, B3: A. pseudogonyaulax AP2T, B4: A. andersonii 012b, C1: A. taylori AY2T, C2: A. affine CCMP 112, C3: A. tamarense BAH ME 182, C4: A. catanella BAH ME 217, D1: A. tamarense 31/4, D2: A. tamarense SZN01, D3: G. varians CCMP 421 and D4: P. parkae CCMP 724.

\subsection{Optimisation of the hybridisation protocol}

The probes that have been previously shown to be specific for A. ostenfeldii in the dot-blot-assay have been used for a sandwich hybridisation of rRNA on a sensor chip. The hybridisation was carried out according to the protocol described in the Section 2. It was possible to measure A. ostenfeldii rRNA isolated from a laboratory strain with the handheld device. A calibration curve was established for different rRNA concentrations (Fig. 3). The signal intensity was proportional to the rRNA concentration applied to the sensor. However, the calibration curve revealed a detection limit of $\sim 100 \mathrm{ng} / \mu \mathrm{l}$ rRNA for the handheld device. At this concentration the signal is $\sim 2 \times$ above the signal of the negative control. In average, it was possible to isolate $0.02 \mathrm{ng}$ rRNA from a single cell (data not shown). If it is considered, that 250 cells/l of Alexandrium cells would be the limit for a closure of a muscle-bed, a detection level of $100 \mathrm{ng} / \mu \mathrm{l}$ would require at least a sampling volume of 401 to gain enough rRNA for a detection of this cell concentration with the handheld device. Therefore, the existing hybridisation protocol needed to be optimised in order to increase the sensitivity of the method. With this regard, parameters of the hybridisation protocol that were known from literature to influence the result of a hybridisation reaction have been optimised. The quantitative results shown in the following sections are based on measurements from eight independent hybridisations originating from two different RNA isolations.

\subsection{Salt concentration and hybridisation temperature}

The hybridisation of two single stranded nucleic acids is determined by the salt concentration in the hybridisation buffer and the hybridisation temperature. In the standard protocol $46^{\circ} \mathrm{C}$ hybridisation temperature and a salt concentration of $75 \mathrm{mM}$ were suggested as hybridisation conditions. However, a determination of the melting temperature (Breslauer et al., 1986) of the probes for A. ostenfeldii revealed that $46^{\circ} \mathrm{C}$ is $\sim 20^{\circ} \mathrm{C}$ below the calculated melting temperature of the probes, which is $64.3^{\circ} \mathrm{C}$ for AOST1 and $66^{\circ} \mathrm{C}$ for AOST2. Therefore, different hybridisation temperatures and salt concentrations were tested in respect to their effect on the hybridisation signal. Hybridisation signals resulting from hybridisations at $46^{\circ} \mathrm{C}, 50^{\circ} \mathrm{C}, 55^{\circ} \mathrm{C}$ and $60^{\circ} \mathrm{C}$ were compared to each other. The strongest reliable improvement of the hybridisation signal was observed at $55^{\circ} \mathrm{C}$. A hybridisation temperature of $55^{\circ} \mathrm{C}$ was discov- 


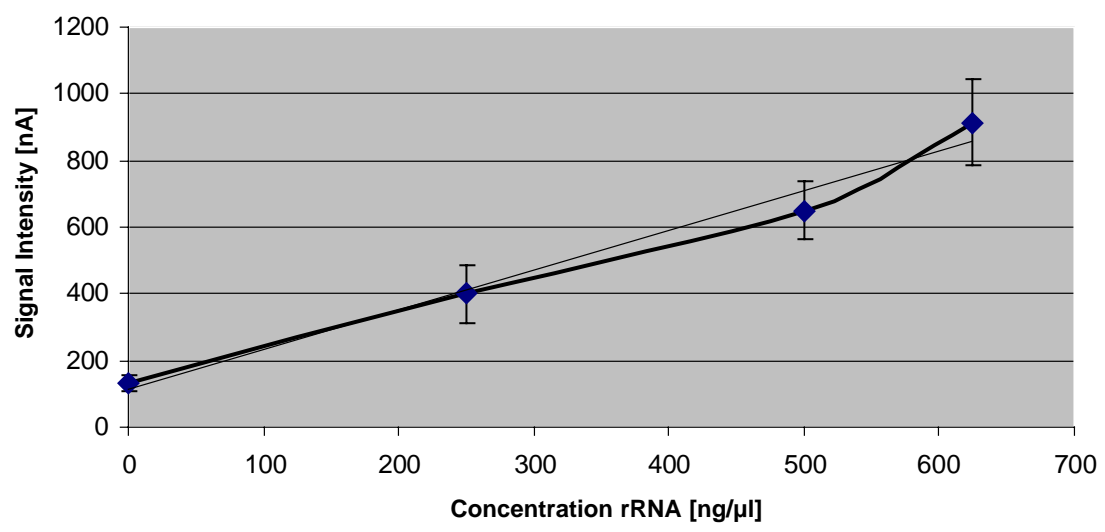

Fig. 3. Calibration curve of different rRNA concentrations. The indicated rRNA concentrations have been hybridised to the sensor according to the standard protocol.

ered to increase the hybridisation signal 2.9-fold. In addition, $\mathrm{NaCl}$-concentrations of $75 \mathrm{mM}, 150 \mathrm{mM}, 300 \mathrm{mM}$ and $600 \mathrm{mM}$ were tested to optimise the hybridisation signal. The strongest improvement of the hybridisation signal was observed for a NaCl-concentration of $150 \mathrm{mM}$. At this concentration the hybridisation signal was increased 2.3-fold in comparison to the original salt concentration of $75 \mathrm{mM}$ (Fig. 4).

\subsection{Helper oligonucleotides}

In previous publications, it has been discussed that the secondary structure of the 16S-rRNA could entail problems in hybridisation experiments (Fuchs et al., 1998; Behrens et al., 2003). It was reported for FISH (fluorescence in situ hybridisation) that the problems caused by the higher-order structure could be overcome by the addition of unlabeled helper oligonucleotides that bind in close proximity to the probes. In this respect, the helper oligonucleotides have a synergistic effect for the probe binding (Fuchs et al., 2000). Here, we present a detection system that targets the 18S-rRNA, which is also known to form intense higher order structures (Behrens et al., 2003). It was examined, if the ap- plication of a helper oligonucleotide would also improve the result of the sandwich hybridisation on the sensor chip. With this regard a helper oligonucleotide was designed (Table 1), which has a similar hybridisation temperature like the target specific probes. The binding site of the oligonucleotide is located in-between the two 18S-rRNA targeted probes. However, the sequence of the oligonucleotide is not specific for the target organism. If the helper oligonucleotide was added in a hybridisation experiment it could be observed that the hybridisation signal in the presence of the helper oligonucleotide was $1.8 \times$ higher than the signal observed for a hybridisation in absence of the helper oligonucleotide (Fig. 4).

\subsection{Fragmentation of the rRNA}

As an alternative strategy to overcome the problems caused by higher-order structures it was tested if a fragmentation of the RNA would positively influence the hybridisation signal. By the generation of smaller sized nucleic acids a fragmentation of the RNA could avoid higher-order structures and antagonise negative effects on the hybridisation efficiency caused by steric hindrance because of the size of the target nucleic acid. For fragmentation, the RNA

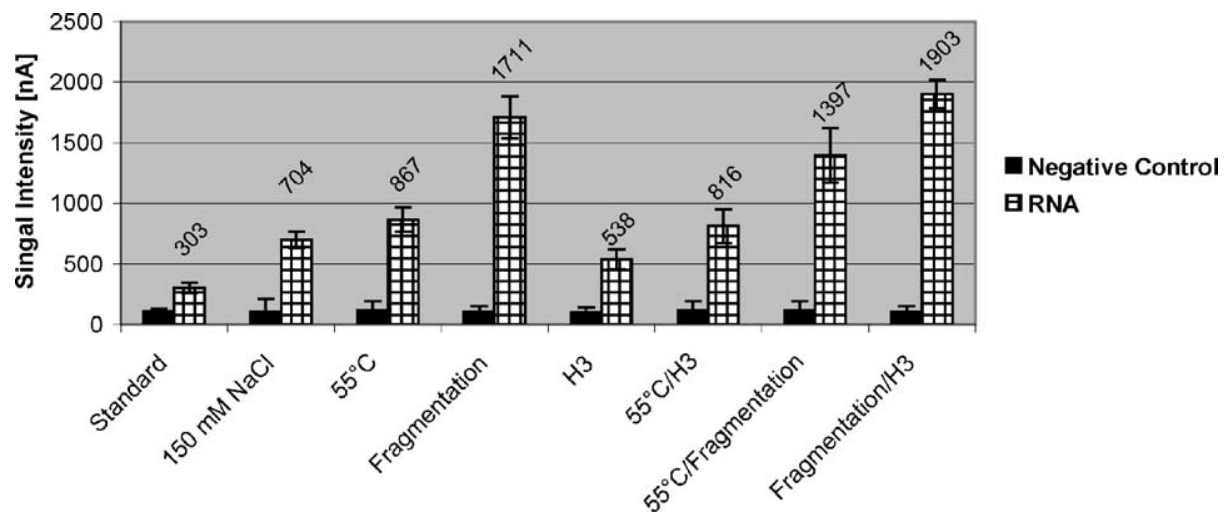

Fig. 4. Optimised hybridisation conditions. All experiments were done with rRNA from the same isolation. The final concentration of the rRNA was $194 \mathrm{ng} / \mu \mathrm{l}$. 
was incubated at $94{ }^{\circ} \mathrm{C}$ over periods of $5 \mathrm{~min}, 10 \mathrm{~min}$ and $35 \mathrm{~min}$. It could be observed that a short incubation of the RNA over a period of $5 \mathrm{~min}$ resulted in an increased signal intensity of $5.7 \times$ compared to the non-fragmented RNA (Fig. 4). However, the signal decreased if the incubation was extended to $10 \mathrm{~min}$ and falls even below the signal intensity of the non-fragmented RNA if it is incubated for 35 min (data not shown).

\subsection{Combination of the optimised hybridisation conditions}

In the previously described experiments various parameters that influence a hybridisation have been optimised. It was expected that a combination of parameters that antagonise the negative influence of the secondary structure on hybridisations like temperature, helper oligonucleotide and fragmentation of the rRNA, would have a synergistic effect on the signal intensity. However, it was observed that only the combination of the helper oligonucleotide with the fragmentation step had a weak synergistic effect in comparison to the fragmentation alone (Fig. 4). This led us to the conclusion that the optimal hybridisation protocol consists of a fragmentation step with an incubation of $5 \mathrm{~min}$ at $94^{\circ} \mathrm{C}$, a hybridisation temperature of $46^{\circ} \mathrm{C}$ and the addition of a helper oligonucleotide that binds in close proximity to the target specific probe (Fig. 4). With the optimised protocol it was possible to increase the signal intensity $6.3 \times$ in comparison to the standard protocol.

\subsection{Application of the detection system}

The specificity of the optimised protocol was examined in accordance to the dot-blot-assay. The rRNA isolated from three different strains of $A$. ostenfeldii and the nearest neigh- bours in the phylogenetic tree (John et al., 2003) were used for the sandwich hybridisation on a sensor chip. The results of the hybridisation reveal that the normalised signal of the rRNA isolated from different strains of A. ostenfeldii is significantly higher than the signal of all non-target organisms (Fig. 5). However, there is a weak cross hybridisation of the probes with A. minutum (AL3T) and A. lusitanicum (BAH ME91), which are the nearest neighbours of $A$. ostenfeldii in a phylogenetic tree analysis (John et al., 2003).

\section{Discussion}

Here, we present a chip-based electrochemical biosensor for the identification of the toxic dinoflagellate A. ostenfeldii via a sandwich hybridisation on molecular level. The biosensor is an inexpensive, easy and rapid technology for the identification of phytoplankton. Electrochemical readings of the handheld device and the protocols are unambiguous and even for a scientific layperson easy to use and interpret. Therefore, this system has great potential to serve as an alternative to conventional methods that are time consuming and expensive. In this publication, the sandwich hybridisation is based on two probes that specifically target the 18S-rRNA of A. ostenfeldii. Probes that target rRNA sequences are routinely applied for the detection of microalgae e.g., in combination with fluorescent in situ hybridisation or dot-blot-assays (Guillou et al., 1999; Simon et al., 2000). The use of rRNA for the identification of organisms with the DNA-biosensor is advantageous because the molecule is present in high numbers in a cell. In prokaryotes up to $80 \%$ of the RNA is rRNA (Woese, 1987). This circumvents an amplification of the target sequence, which is part of other DNA-biosensor protocols (Baeumner et al., 2003; Hartley and Baeumner, 2003; Litaker et al., 2000).

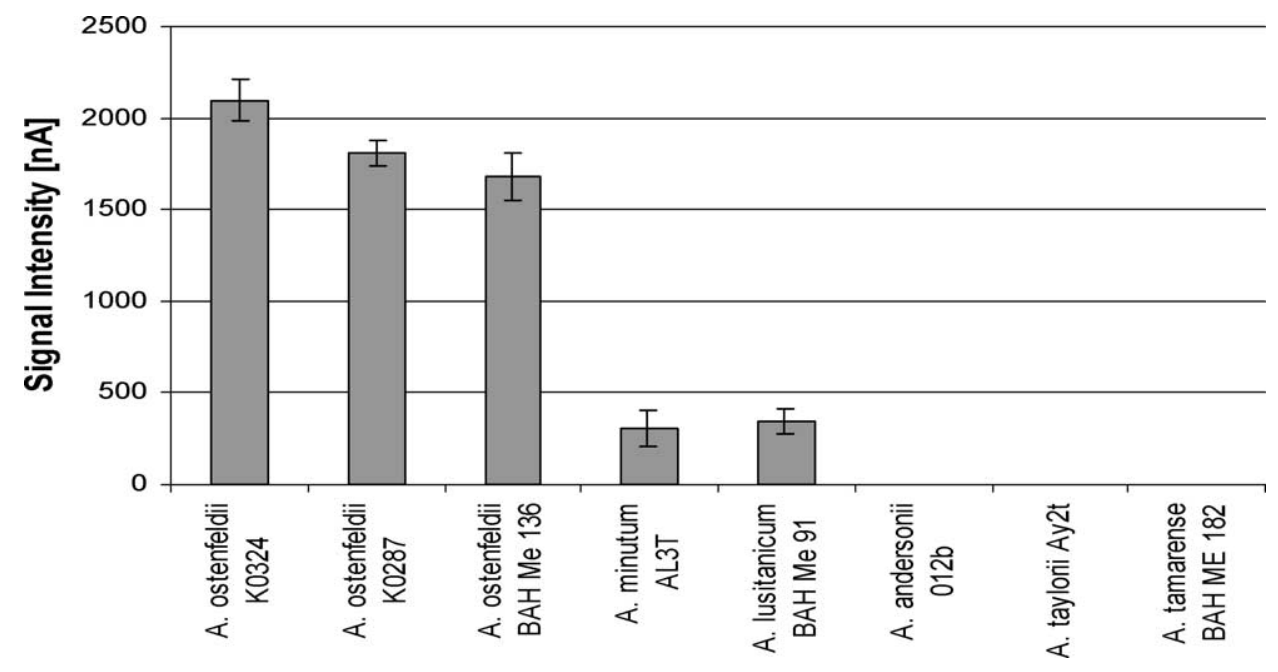

Fig. 5. The specificity of the DNA-biosensor was tested using RNA of the following Alexandrium species: A. ostenfeldii K0324, [0] K0287, BAH ME 136; A. minutum AL3T, A. lusitanicum BAH ME 91, A. andersonii 012b, A. taylorii AY2T, A. tamarense BAH ME 182. The concentration of the rRNA was $250 \mathrm{ng} / \mu \mathrm{l}$ for all tested species. 


\subsection{Probes}

The probes were designed using the ARB software package (Ludwig et al., 2004). The specificity of the probe set was determined theoretically by comparing the sequences with the sequences in the local ARB database and by doing a blast-search against all public available sequences (Altschul et al., 1990). In practice, the specificity of the probes was shown in a dot-blot-assay and with the DNA-biosensor itself. In accordance to the theory, with both methods the signal for the target species was always significantly above the signal for any non-target organism. To test the specificity of the probes those species have been tested that had the lowest number of mismatches to the target species and were the closest relatives in the phylogenetic tree. It was set aside to test more distantly related species because those species with the lowest number of mismatches would have the highest probability to result in an unspecific signal. High numbers of mismatches antagonise probe binding. Therefore, more distantly related species with higher numbers of mismatches are not very likely to bind to the probe. It is unlikely that a probe, which does not bind to a close relative of a target species, would bind to more distantly related species, which would have more mismatches. However, a weak cross hybridisation was observed with the biosensor for A. lusitanicum and A. minutum, which are the next neighbours of $A$. ostenfeldii in the phylogenetic tree. The main goal of the biosensor is the detection of a toxic algae. A. minutum and A. lusitanicum are synonyms for the same species (IOC, 2002) with the potential to cause paralytic shell fish poisoning (Chang et al., 1997; Hold et al., 2001). Even if a signal would be only derived from A. minutum it would still account for a serious threat. However, it has to be considered that the number of sequences available in the databases reflects only a small amount of the number of species present in the environment. Therefore, it is important to re-evaluate the specificity of rRNA targeted probes on a regular basis in respect to the continually growing number of algal $18 \mathrm{~S}$ rRNA sequences in public databases e.g., in the ribosomal database project (RPD) (Maidak et al., 2001). The probes for the sandwich hybridisation have been chosen with regard to the distance of their binding sites in the 18S-rRNA molecule. RNA is highly susceptible to degradation. To avoid effects of degradation on the success of the sandwich hybridisation, it was intended to choose a specific probe set with binding sites in close proximity to each other. A sandwich hybridisation based on probes that are located at a bigger distance to each other are probably more vulnerable to effects of degradation because it is very likely that a larger molecule is fragmented, which would prevent the two probes from binding to the same molecule.

\subsection{Optimisation of the hybridisation protocol}

A preliminary hybridisation protocol had to be optimised with regard to the sensitivity of the method. Single param- eters of the hybridisation protocol like $\mathrm{NaCl}$-concentration in the hybridisation buffer, hybridisation temperature, addition of a helper-oligonucleotide, or a fragmentation of the rRNA prior to the hybridisation were optimised separately in regard to the hybridisation signal. However, a combination of the optimised parameters resulted only in a weak synergistic effect if the fragmentation was combined with an addition of the helper oligonucleotide. The weak synergistic effect of the optimised parameters could be explained in the way that the optimised hybridisation parameters aim all to break up the higher-order structures of the target molecule. It is likely that the secondary structure was already almost dissolved if a single optimised hybridisation parameter was applied and therefore, leaves only little scope to further increase the signal intensity by combining two optimal factors. However, with the optimised protocol it was possible to increase the signal intensity by a factor of 6.3. As a consequence, the detection limit of the device is decreased accordingly. If the detection limit of the device was $100 \mathrm{ng} / \mu \mathrm{l}$ with the standard protocol, it is $\sim 16 \mathrm{ng} / \mu \mathrm{l}$ with the optimised protocol. With an average yield of $0.02 \mathrm{ng} / \mathrm{cell}$ this equals 800 cells or a sampling volume of 6.41 to get a detectable amount of rRNA from 250 cells/liter.

\subsection{Limitations of the system}

Besides the good performance of the device for the identification of laboratory strains, it has to be determined, how the device performs in field tests. This means in particular, that it has to be examined, if it is possible to correlate signal intensities with cell counts from water samples. Currently, the system is limited by the manual isolation of rRNA. It is possible that differently experienced users could isolate different amounts of rRNA from the same number of algae cells, resulting in signal intensities that do not reflect the real situation in terms of cell counts. In order to ensure reliable and reproducible results it is desirable to automate the isolation of rRNA. Also, the system has to be adapted to the wide variety of toxic algae.

\section{Conclusion}

A DNA-biosensor was adapted to the electrochemical detection of the toxic dinoflagellate A. ostenfeldii and the sensitivity of the DNA-biosensor was increased by an optimisation of the hybridisation conditions. The electrochemical DNA-biosensor presented in this publication is a proof of principle for a DNA-handheld device that possesses the potential to serve as a quick and easy method for the identification of toxic algae. The device could facilitate the work that must be done in the course of monitoring toxic algae by eliminating the need to count algae and reduce the need for mouse bioassay. 


\section{Acknowledgements}

We would like to thank Inventus Biotec, Germany, for excellent cooperation with regard to the allocation of the handheld device, the disposable sensor chips and the adaptation of the glucose sensor chips to our needs, as well as for valuable discussion.

\section{References}

Altschul, S.F., Gish, W., Miller, W., Myers, E.W., Lipman, D.J., 1990. Basic local alingment search tool. J. Mol. Bio. 215, 403-410.

Baeumner, A.J., Cohen, R.N., Miksic, V., Min, J., 2003. RNA biosensor for the rapid detection of viable Escherichia coli in drinking water. Biosens. Bioelectron. 18, 405-413.

Balech, E., 1995. The genus Alexandrium halim (Dinoflagellata). Sherkin Island Marine Station Publication, Sherkin Island, Co., Cork, Ireland.

Balech, E., Tangen, K., 1985. Morphology and taxonomy of toxic species in the tamarensis group (Dinophyceae): Alexandrium excavatum (Braarud) comb. nov. and Alexandrium ostenfeldii (Paulsen) comb. nov. Sarsia 70, 333-343.

Behrens, S., Ruhland, C., Inacio, J., Huber, H., Fonseca, A., Spencer-Martins, I., Fuchs, B.M., Amann, R., 2003. In situ accessibility of small-subunit rRNA of members of the domains Bacteria, Archaea and Eucarya to Cy3-labeled oligonucleotide probes. Appl. Environ. Microbiol. 69 (3), 1748-1758.

Breslauer, K.J., Frank, R., Blocker, H., Marky, L.A., 1986. Predicting DNA duplex stability from the base sequence. Proc. Natl. Acad. Sci. U.S.A. 83, 3746-3750.

Cembella, A.D., 1998. Exophysiology and metabolism of paralytic shellfisch toxins in marine microalgae. In: Anderson, D.M., Cembella, A.D., Hallegraeff, G.M. (Eds.), Physiological Ecology of Harmful Algal Blooms, Springer Verlag, Berlin.

Cembella, A.D., Lewis, N.I., Quilliam, M.A., 1999. Spirolide composition of micro-extracted pooled cells isolated from natural plankton assemblages and from cultures of the dinoflagellate Alexandrium ostenfeldii. Nat. Toxins. 7 (5), 197-206.

Cembella, A.D., Lewis, N.I., Quilliam, M.A., 2000. The marine dinoflagellate Alexandrium ostenfeldii (Dinophyceae) as the causative organism of spirolide shellfish toxin. Phycologia 39, 67-74.

Chang, F.H., Anderson, D.M., Kulis, D.M., Till, D.G., 1997. Toxin production of Alexandrium minutum (Dinophyceae) from the Bay of Plenty, New Zealand. Toxicon 35, 393-409.

Fogg, G.E., 2002. Harmful algae-perspective. Harmful Algae 1, 1-4.

Fraga, S., Sanchez, F.J., 1985. Toxic and potentially toxic dinoflagellates in Galician Rias (NW Spain). Toxic Dinoflagellates, In: Proceedings of Third International Conference on Toxic Dinoflagellates, Elsevier, New York.

Fuchs, B.M., Wallner, G., Beisker, W., Schwippl, I., Ludwig, W., Amann, R., 1998. Flow cytometric analysis of the in situ accessibility of Escherichia coli 16S rRNA for fluorescently labelled oligonucleotide probes. Appl. Environ. Microbiol. 64, 4973-4982.

Fuchs, B.M., Glöckner, F.O., Wulf, J., Amann, R., 2000. Unlabelled helper oligonucleotides increase the in situ accessibility to 16S rRNA of fluorescently labelled oligonucleotide probes. Appl. Environ. Microbiol. 66 (8), 3603-3607.

Guillou, L., Moon-van-der-Staay, S.Y., Claustre, H., Partensky, F., Vaulot, D., 1999. Diversity and abundance of Bolidophyceae (Heterokonta) in two oceanic regions. Appl. Environ. Microbiol. 65, 45284536.

Hallegraeff, G.M., 1993. A review of harmful algal blooms and their apparent global increase. Phycologia 32, 79-99.

Hallegraeff, G.M., 1995. Harmful algal blooms: a global overview. In: Hallegraeff, G.M., Anderson, D.M., Cembella, A.D. (Eds.), Manual on Harmful Marine Microalgae, IOC Manuals and Guides 33. UNESCO.
Hansen-Ostenfeld, C., 1913. De danske farvandes plankton i arene 1898-1901. K. danske Vidensk. Sels, Skr., 7. Raekke, Afd. 9 (2), $117-478$.

Hansen, P.J., Cembella, A.D., Moestrup, Ø., 1992. The marine dinoflagellate Alexandrium ostenfeldii: paralytic shellfish toxin concentration, composition and toxicity to a tintinnid ciliate. J. Phycol. 28, 597603.

Hartley, H.A., Baeumner, A.J., 2003. Biosensor for the specific detection of a single viable B. anthracis spore. Anal. Bioanal. Chem. 376, 319327.

Hold, G.L., Smith, E.A., Birkbeck, T.H., Gallacher, S., 2001. Comparison of paralytic shellfish toxin (PST) production by the dinoflagellates Alexandrium lusitanicum NEPCC 253 and Alexandrium tamarense NEPCC 407 in the presence and absence of bacteria. FEMS Microbiol. Ecol. 36, 223-234.

Hu, T., Burton, I.W., Cembella, A.D., Curtis, J.M., Quilliam, M.A., Walter, J.A., Wright, J.L., 2001. Characterization of spirolides a, c and 13-desmethyl c, new marine toxins isolated from toxic plankton and contaminated shellfish. J. Nat. Prod. 64 (3), 308-312.

IOC, 2002. Taxonomic Reference List of Toxic Plankton Algae, Intergovernmental Oceanographic Comission of UNESCO.

John, U., Fensome, R.A., Medlin, L.K., 2003. The application of a molecular clock based on molecular sequences and the fossil record to explain biogeographic distributions within the Alexandrium tamarense "species complex" (Dinophyceae). Mol. Biol. E 20, 10151027.

Keller, M.D., Selvin, R.C., Claus, W., Guillard, R.R.L., 1987. Media for the culture of oceanic ultraphytoplankton. J. Phycol. 23, 633638.

Konovalova, G.V., 1991. The morphology of Alexandrium ostenfeldii (Dinophyta) from the coastal waters of Eastern Kamchatka. Botanicheskii Zhurnal (Leningrad) 76, 76 79-82.

Lange, M., Medlin, L.K., 2002. Design and testing of ITS probes for distinguishing Phaeocystis species. Protist 153, 275-282.

Lim, E.L., Amaral, L.A., Caron, D.A., DeLong, E.F., 1993. Application of rRNA-based probes for observing marine nanoplanktonic protists. Appl. Envrion. Microbiol. 59, 1647-1655.

Litaker, W., Sundseth, R., Wojciechowski, M., Bonaventura, C., Henkens, R., Tester, P., 2000. Electrochemical detection of DNA or RNA from harmful algal bloom species. Harmful Algal Bloom 242-245.

Ludwig, W., Strunk, O., Westram, R., Richter, L., Meier, H., Yadhukumar, Buchner, A., Lai, T., Steppi, S., Jobb, G., Forster, W., Brettske, I., Gerber, S., Ginhart, A.W., Gross, O., Grumann, S., Hermann, S., Jost, R., Konig, A., Liss, T., Lussmann, R., May, M., Nonhoff, B., Reichel, B., Strehlow, R., Stamatakis, A., Stuckmann, N., Vilbig, A., Lenke, M., Ludwig, T., Bode, A., Schleifer, K.H., 2004. ARB: a software environment for sequence data. Nucleic Acid Res. 32(4), 13631371.

Maidak, B.L., Cole, J.R., Lilburn, T.G., Parker, C.T.J., Saxman, P.R., Farris, R.J., Garrity, G.M., Olson, G.J., Schmidt, T.M., Tiedje, J.M., 2001. The RDP-II (ribosomal database project). Nucleic Acids Res. 29, 173-174.

McKenzie, L., White, D., Yasukatsu, O., Kapa, J., 1996. The resting cyst and toxicity of Alexandrium ostenfeldii (Dinophyceae) in New Zealand. Phycologia 35, 148-155.

Medlin, L.K., Elwood, H.J., Stickel, S., Sogin, M.L., 1988. The characterization of enzymatically amplified eukaryotic 16S-like rRNA-coding regions. Gene 71, 491-499.

Moestrup, Ø., Hansen, P.J., 1988. On the occurrence of the potentially toxic dinoflagellates Alexandrium tamarense (=Gonyaulax excavata) and A. ostenfeldii in Danish and Faroese waters. Ophelia 28, 195213.

Rautio, J., Barken, K.B., Lahdenpera, J., Breitenstein, A., Molin, S., Neubauer, P., 2003. Sandwich hybridisation assay for quantitative detection of yeast RNAs in crude cell lysates. Microb. Cell Fact. 2 (1), 4. 
Scholin, C.A., Anderson, D.M., 1998. Detection and quantification of HAB species using antibody and DNA probes: progress to date and future research objectives. Harmful Algae 253-257.

Simon, N., Campbell, L., Ornolfsdottir, E., Groben, R., Guillou, L., Lange, M., Medlin, L.K., 2000. Oligonucleotide probes for the identification of three algal groups by dot-blot and fluorescent whole-cell hybridization. J. Eukaryot. Microbiol. 47 (1), 76-84.

Sournia, A., Chretiennot, D., Ricard, M., 1991. Marine Phytoplankton: how many species in the world ocean? J. Plankton Res. 13, 10931099.
Taylor, R.J.R., 1985. The taxonomy and relationships of red tide flagellates. In: Anderson, D.M., et al. (Eds.), Toxic Dinoflagellates. Elsevier, New York.

Woese, C.R., 1987. Bacterial evolution. Microbiol. Rev. 51, 221271

Zammatteo, N., Moris, P., Alexandre, I., Vaira, D., Piette, J., Remacle, J., 1995. DNA probe hybridisation in microwells using a new bioluminescent system for the detection of PCR-amplified HIV-1 proviral DNA. J. Virol. Methods 55 (2), 185-197. 